\title{
A Systematic Review: Standard Measurement method of Anguli pramana
}

\author{
Review Article
}

Visave Pratibha ${ }^{*}$, Deepnarayan Shukla ${ }^{2}$, Deepali Choudhari ${ }^{3}$

1. Associate Professor, Siddhakala Ayurved College, Sangamner, Maharashtra

2. H.O.D. \& Professor, Department of Rachana Sharir, R. A. Podar Ayurved Medical College, Mumbai

3. H.O.D. \& Associate Professor S.S.T. Ayurved College, Sangamner, Maharashtra

\begin{abstract}
Introduction: Anguli pramana is an ancient form of anthropometric measurements where individual's own finger width is used as a unit of measurement. Different researchers had attempted to standardize the Anguli pramana. This systematic review aims to review all the available published literature and to provide the narrative summary on Anguli pramana. Methods: References were sought in Google scholar, AYUSH Research portal, DHARA online, Pub med, Shodhganga, eShodhSindhu datasets and other sources like Grey literature by utilizing all the keywords and MeSH terminologies. Following PRISMA guidelines, 32 full-text eligible papers were assessed and 9 articles extracted for study design, population parameters, methodology, evaluation system, outcome and other relevant findings. Result: 5 out of 9 studies have reconfirmed that breadth of middle finger (BM) of right hand proved as more accurate method of measurement in Anguli pramana while in 3 studies average of right and left middle finger at proximal interphalangeal joint is used as a method of measurement. Only 1 study shows use of average of breadth of four fingers at metacarpophalangeal joints of right and left hand as a method of measurement. Discussion: Present systematic review concludes that breadth of middle finger of the right hand at proximal interphalangeal joint $(\mathrm{BM})$ is the standard method of measurement for Anguli pramana.
\end{abstract}

Key Words: Anguli pramana, Systematic review, Standard method, Measurement, Breadth of middle finger.

\section{Introduction}

Anguli pramana is an ancient form of anthropometric measurement where individual's own finger width is used as a unit of measurement. In Ayurveda, the term 'anguli' (breadth of one's own finger) has been accepted as smallest unit for measuring body parts. (1) Various references from ancient texts explain that Pramana sharira plays important role in determination of life span as well as the quality of life. The persons having appropriate measurement may attain a long span life span and prosperity; with moderate and poor measurements, they may attain medium and short lives respectively. (2) It is a unique method of assessment of health and nutritional status of an individual. Different researchers had attempted to standardize the Anguli pramana.

In ancient method of measurement exactly which finger should be used for measurement is not mentioned by acharya Charak and Sushruta. But there are some references in classical texts like Kautiliya Arthashastra and Sharangdhar Samhita in this regard. Said references reveal that Anguli pramana can be taken as,

\section{* Corresponding Author:}

\section{Visave Pratibha}

Associate Professor, Department of Rachana Sharir,

Siddhakala Ayurved College, Sangamner,

Dist. Ahmednagar, Maharashtra. India

Email Id: pratibha.pps@gmail.com
1. Width of middle finger at proximal interphalangeal joint, (3) (4)

2. Width of proximal end of nail of thumb, (4) (5)

3. Measurement obtained by taking width of the palm and then dividing it by four. (6) (7)

Considering such kind of various opinions about Anguli pramana there was a pressing need to find out standard method of measurement technique in Anguli pramana. Present systematic review includes all the previous studies in concerned topic i.e. both Anguli pramana and standard method of measurement of the same as primary or secondary outcome. This systematic review aims to review all the published literature and to provide comprehensive details on Anguli pramana.

\section{Materials and methods \\ Literature Search Strategy}

The preferred reporting items of systematic review and meta-analysis (PRISMA) guidelines were followed while conducting this systematic review. (8) The studies in this systematic review were selected on the basis of protocol described in (9) that defines the search strategy, inclusion criteria, information extraction process etc.

A systematic search was conducted on six libraries or databases including Google scholar, AYUSH Research portal, DHARA online, Pub med, Shodhganga, eShodhSindhu and other sources like Grey literature by utilizing all the keywords and $\mathrm{MeSH}$ terminologies related to the topic of interest. Table 1 shows search strategy based on key words for various 
datasets. The search was performed in April 2020. There was no time limitation in the search period.

Table 1. Search strategy based on keywords for various datasets

\begin{tabular}{|c|c|c|}
\hline Dataset & Query & $\begin{array}{l}\text { Items } \\
\text { found }\end{array}$ \\
\hline $\begin{array}{l}\text { Google } \\
\text { scholar }\end{array}$ & $\begin{array}{l}\text { Anguli pariman, } \\
\text { anthropometry, rachana } \\
\text { sharir, shareera rachana, } \\
\text { pramana sharir, } \\
\text { anthropometric study, pilot } \\
\text { study, standardization, } \\
\text { a } \mathrm{n} \text { h } \mathrm{r} \text { o m e t r c } \\
\text { measurements, middle } \\
\text { finger width (using Boolean } \\
\text { logics AND, OR, NOT). }\end{array}$ & 2680 \\
\hline $\begin{array}{l}\text { AYUSH } \\
\text { Research } \\
\text { portal }\end{array}$ & -do- & 7 \\
\hline $\begin{array}{l}\text { DHARA } \\
\text { online }\end{array}$ & -do- & 7 \\
\hline Pub med & -do- & 6 \\
\hline Shodhganga & -do- & 3 \\
\hline $\begin{array}{l}\text { eShodh } \\
\text { Sindhu }\end{array}$ & -do- & 5 \\
\hline $\begin{array}{l}\text { Grey } \\
\text { literature } \\
\text { sources }\end{array}$ & -do- & 3 \\
\hline
\end{tabular}

\section{Inclusion and Exclusion criteria}

This study focused on Anguli pramana, an ancient method of body measurements. In order to be included, the article must have reported data about both Anguli pramana and standard method of measurement of it as primary or secondary outcome. We excluded editorial, letters and meeting abstracts. Inappropriate articles were excluded from the study for following reasons; a) not related to topic, b) irrelevant data for analysis, c) unavailable abstract or full-text, d) review articles. Two authors conducted this step to evaluate the eligibility of each article. Afterwards, qualification of each article was assessed by reading the full-text; in addition a manual search was also performed by screening the reference list of the selected articles. In case of conflict, opinion of third author was sought. The qualified articles were subjected to the next step of data extraction.

\section{Data Extraction}

The data was extracted concerning the purpose of the study: first author, year, study design, number of participants, parameters, age, remark of assessment, outcome and other relevant findings. Importantly, we extracted the method of measurement for Anguli pramana. When study reported several parameters or models with different degree of adjustment, we extracted all of them in order to get further information. The analyses which exceeded or didn't fit the purpose of this review were not considered.

\section{Results}

\section{Study Selection}

Following a systematic search that mainly focused on Anguli pramana and standard method of measurement as primary or secondary outcome, we retrieved 2680, 7, 7, 6, 3, 5 and 3 articles from Google scholar, AYUSH Research portal, DHARA online, Pub med, Shodhganga, eShodhSindhu and other sources like Grey literature respectively. Thus, we identified 2711 potentially relevant records utilizing all the keywords and MeSH terminologies related to the topic of interest. Subsequently duplicate records were removed. After that, the titles and abstracts of the remaining records were screened for eligibility leading to extraction process. Finally, 32 articles were included for full-text screening and 9 qualified articles remained for the process of data extraction. Complete workflow is displayed in Figure 1.

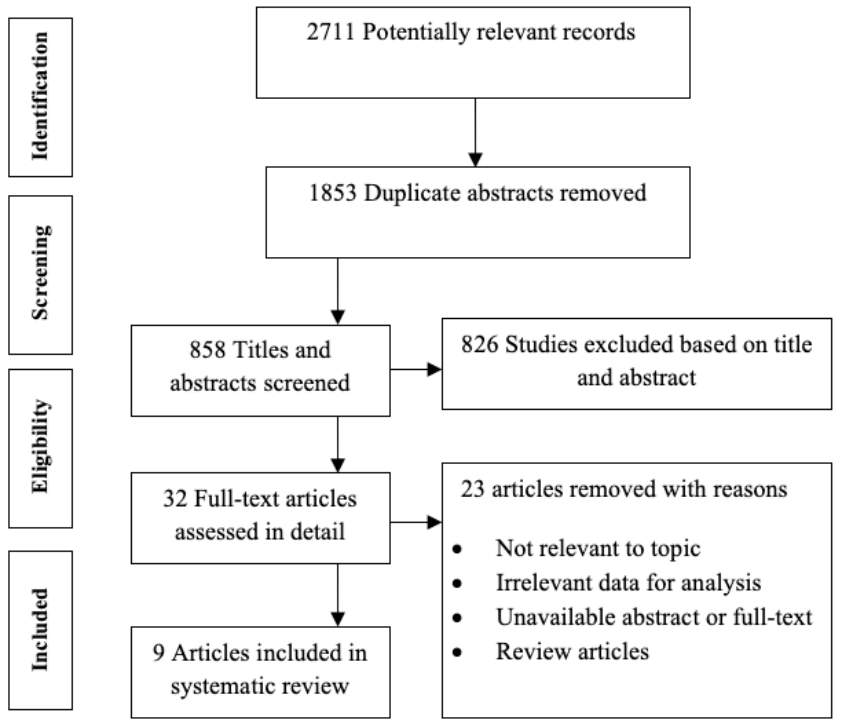

Figure 1. Flow chart of data selection process

\section{Characteristics of Selected Studies}

The main characteristics and results of the selected articles are shown in Table 2. We found nine original articles assessing the correlation of method of measurement and Anguli pramana. All of the studies were conducted in different parts of India and all of them including apparently healthy participants. Most of the study includes a representative sample of minimum 60 participants which itself indicates the quality of the study. All the articles included in this systematic review are published between 2013 and 2019. The sample size ranges from 60 to 1000; and the age of participants ranges from 16 to 70 years. All the studies were observational in study design. 


\section{Table 2. Characteristics of Selected Studies}

\begin{tabular}{|c|c|c|c|c|c|c|c|}
\hline $\begin{array}{l}\text { Author } \\
\text { Year }\end{array}$ & $\begin{array}{r}\text { Study } \\
\text { design }\end{array}$ & Participants & Parameters & Age & $\begin{array}{c}\text { Remark of } \\
\text { Assessment }\end{array}$ & Outcome & Other findings \\
\hline $\begin{array}{l}\text { S. } \\
\text { Muley } \\
2013 \\
(10)\end{array}$ & $\begin{array}{l}\text { Observ } \\
\text { ational }\end{array}$ & $\mathrm{N}=100$ & Aayam, vistar & $16-70$ & $\begin{array}{l}\text { Coefficient } \\
\text { correlation } \\
\text { between } \\
\text { aayam \& vistar }\end{array}$ & $\begin{array}{l}\text { Correlation }(0.24) \\
\text { between aayam \& } \\
\text { vistar }\end{array}$ & $\begin{array}{l}\text { Average of Rt. \& Lt } \\
\text { hand mediolateral } \\
\text { proximal } \\
\text { interphalangeal } \\
\text { joint of middle } \\
\text { finger }\end{array}$ \\
\hline $\begin{array}{l}\text { R. Pai } \\
2017 \\
(11)\end{array}$ & $\begin{array}{l}\text { Observ } \\
\text { ational }\end{array}$ & $\mathrm{N}=1000$ & $\begin{array}{l}\text { Limbs, thorax, } \\
\text { abdomen, head } \\
\& \text { neck length } \\
\text { and cir., stature, } \\
\text { prakruti }\end{array}$ & $25-45$ & $\begin{array}{l}\text { One way } \\
\text { ANNOVA }\end{array}$ & $\begin{array}{l}\text { No significant } \\
\text { Difference between } \\
\text { pramana } \\
\text { in } 3 \text { different } \\
\text { Prakruti and } \\
\text { also with granthokta } \\
\text { pramana }\end{array}$ & $\begin{array}{l}\text { Width of middle } \\
\text { finger } \\
\text { seems to be more } \\
\text { relevant than other } \\
\text { methods }\end{array}$ \\
\hline $\begin{array}{l}\text { R. } \\
\text { Sharma } \\
2015 \\
(12)\end{array}$ & $\begin{array}{l}\text { Observ } \\
\text { ational }\end{array}$ & $\mathrm{N}=150$ & $\begin{array}{l}\text { Shir, skandha, } \\
\text { aratni, } \\
\text { prabahu, } \\
\text { prapani, } \\
\text { jangha, uru, } \\
\text { janu, } \\
\text { gulpha, parshni } \\
\text { length \&cir, } \\
\text { prakruti }\end{array}$ & $18-30$ & $\begin{array}{l}\text { One way } \\
\text { ANNOVA test }\end{array}$ & $\begin{array}{l}\text { No significant } \\
\text { difference } \\
\text { between granthokta } \\
\text { pramana and each } \\
\text { prakruti } \\
\text { in different age } \\
\text { except for head } \\
\text { Cirumference and } \\
\text { length of thigh }\end{array}$ & $\begin{array}{l}\text { Width of proximal } \\
\text { inter } \\
\text { phalangeal joint of } \\
\text { middle finger } \\
\text { preferred } \\
\text { for measurement }\end{array}$ \\
\hline $\begin{array}{l}\text { A. } \\
\text { Shilwant } \\
2018 \\
(13)\end{array}$ & $\begin{array}{l}\text { Observ } \\
\text { ational }\end{array}$ & $\mathrm{N}=100$ & $\begin{array}{l}\text { Cirumference } \\
\text { of chest }\end{array}$ & $17-22$ & $\begin{array}{l}\text { Mean \& range } \\
\text { of chest } \\
\text { circumference }\end{array}$ & $\begin{array}{l}70.97 \% \text { subjects } \\
\text { showing } \\
\text { extensively wide } \\
\text { chest indicates major } \\
\text { contribution of kapha } \\
\text { dosha }\end{array}$ & $\begin{array}{l}\text { Average of distance } \\
\text { between medial \& } \\
\text { lateral edges of } \\
\text { middle finger of } \\
\text { both upper } \\
\text { extremities }\end{array}$ \\
\hline $\begin{array}{l}\text { N. Jain } \\
2017 \\
(14)\end{array}$ & $\begin{array}{l}\text { Observ } \\
\text { ational }\end{array}$ & $\mathrm{N}=100$ & $\begin{array}{l}\text { Length \& } \\
\text { circumference } \\
\text { of lower limb }\end{array}$ & $18-30$ & Mean, S.D. & $\begin{array}{l}\text { Maximum variation } \\
\text { obtained in Uru } \\
\text { aayam } \\
\text { \& Jangha aayam }\end{array}$ & $\begin{array}{l}\text { Various parameter } \\
\text { values measured by } \\
\text { BM } \\
\text { Were nearer to } \\
\text { samhita values }\end{array}$ \\
\hline $\begin{array}{l}\text { S. } \\
\text { Sharath } \\
2013 \\
(15)\end{array}$ & $\begin{array}{l}\text { Observ } \\
\text { ational }\end{array}$ & $\mathrm{N}=100$ & $\begin{array}{l}\text { Length and } \\
\text { circumference } \\
\text { of Jangha, } \\
\text { standing } \\
\text { ht, ht. with } \\
\text { arms rose }\end{array}$ & $20-60$ & $\begin{array}{l}\text { Pearson's } \\
\text { correlation } \\
\text { coefficient }\end{array}$ & $\begin{array}{l}\text { Positive correlation } \\
\text { between mean tibial } \\
\text { length } \\
\& \text { height of } \\
\text { individual }\end{array}$ & $\begin{array}{l}\text { BM is accepted as a } \\
\text { tool of } \\
\text { measurement }\end{array}$ \\
\hline $\begin{array}{l}\text { S. Phule } \\
2019 \\
(16)\end{array}$ & $\begin{array}{l}\text { Observ } \\
\text { ational }\end{array}$ & $\mathrm{N}=60$ & $\begin{array}{l}\text { Total } 43 \\
\text { pratyangas } \\
\text { of the body, } \\
\text { physical } \\
\text { fitness }\end{array}$ & $20-30$ & $\begin{array}{l}\text { Chi- square } \\
\text { test }\end{array}$ & $\begin{array}{l}\text { Positive correlation } \\
\text { Charakokta Anguli } \\
\text { pramana } \\
\text { and Physical fitness }\end{array}$ & $\begin{array}{l}\text { Average of Breadth } \\
\text { of four fingers at } \\
\text { Metacarpo } \\
\text { phalangeal joint of } \\
\text { Rt \& Lt hand }\end{array}$ \\
\hline $\begin{array}{l}\text { S. } \\
\text { Bhutada } \\
2018 \\
(17)\end{array}$ & $\begin{array}{l}\text { Observ } \\
\text { ational }\end{array}$ & $\mathrm{N}=60$ & $\begin{array}{l}\text { Bahu (upper } \\
\text { limb), prakruti }\end{array}$ & $17-22$ & Mean, S.D. & $\begin{array}{l}63.33 \% \text { subjects } \\
\text { showing } \\
\text { Pralamba bahu } \\
\text { involves Kapha } \\
\text { dosha in their } \\
\text { constitutional } \\
\text { make-up }\end{array}$ & $\begin{array}{l}\text { Average of distance } \\
\text { between medial \& } \\
\text { lateral edges of } \\
\text { middle finger of } \\
\text { both upper } \\
\text { extremities }\end{array}$ \\
\hline $\begin{array}{l}\text { Singh A. } \\
2015 \\
(18)\end{array}$ & $\begin{array}{l}\text { Observ } \\
\text { ational }\end{array}$ & $\mathrm{N}=100$ & $\begin{array}{l}\text { Head } \\
\text { circumference, } \\
\text { stature }\end{array}$ & $25-45$ & $\begin{array}{l}\text { Linear } \\
\text { regression } \\
\text { equation }\end{array}$ & $\begin{array}{l}\text { Definite correlation } \\
\text { between stature and } \\
\text { head measurements }\end{array}$ & $\begin{array}{l}\mathrm{BM} \text { is more } \\
\text { accurate for } \\
\text { measurement }\end{array}$ \\
\hline
\end{tabular}

BM: Breadth of middle finger at proximal interphalangeal joint, Cir: circumference, $\mathrm{Ht}$ : height, aayam: human height, vistar: arm span, Shir: head, Skandha: shoulder joint, Aratni: distance from elbow joint to little finger, Prabahu: distance from shoulderjoint to elbow joint, Prapani: from elbow to wrist joint, Jangha: from knee joint to ankle joint , Uru: hip joint to knee joint, Janu: knee joint, Gulpha: ankle joint , Parshni: heels, Pratyanga: body parts, prakruti: constitutional make-up, Granthokta: as per classical text, Kapha dosha: one of the constitutional entity, Uru aayam: length of thigh, Jangha aayam: length of leg, Pralamba bahu: extensively long hanging upper extremity. 


\section{Discussion}

This systematic review shows that all the 9 studies included are observational in study design. In study (10) there is partial positive correlation between aayam (human length) and vistar (arm span) when measurements taken with the average of right and left hand mediolateral proximal interphalangeal joint of middle finger in centimetre as one angul (unit of measurement). Along with this, study confirms that measurement of Anguli pramana with breadth of middle finger (BM) is more accurate than the commonest method i.e. average of four fingers of right and left hand. The study (11) reflects on relation between Pramana (body measurements) and different Prakruti (constitutional make-up). It also confirms that measurements taken with the width of middle finger (BM) is more relevant than other methods. The study (12) deals with assessment of Prakruti (constitutional make-up) using proforma. This study shows closer relation of features of each prakruti (constitutional make-up) assessed is found in concurrence with classical text, except for head circumference and length of thigh. Width of interphalangeal joint of middle finger $(\mathrm{BM})$ is preferred for measurement. The study (13) deals with chest measurement only with outcome stating that $70.97 \%$ subjects having extensively wide chest indicating major contribution of kapha dosha (one of the constitutional entity). Researcher has taken average of distance between medial \& lateral edges of middle finger of both upper extremities. The study (14) includes measurement of left lower limb parameters taken by left BM. Maximum variation obtained in Uru aayam (length of thigh) and Jangha aayam (length of leg). The study (15) states positive correlation between mean tibial length and height of individual where Breadth of middle finger (BM) is accepted as a tool of measurement. The study (16) focused on the correlation of Charakokta Anguli pramana and physical fitness showing positive correlation between the same. Here, measurement tool used is average of breadth of four fingers at metacarpophalangeal joint of right and left hand. The study (17) reveals the assessment of upper limb measurement and prakruti (constitutional makeup) which states that $63.33 \%$ subjects showing Pramaba bahu (extensively long hanging upper extremity) involves Kapha dosha (one of the constitutional entity) in their constitutional make-up. The study (18) reflects definite correlation between stature and head measurements as well as BM is more accurate method for measurement.

Out of nine, two studies (11) (12) have taken one way ANNOVA test for statistical analysis. Two out of nine studies (10) (15) analyzed the data using Pearson's correlation coefficient. The studies (14) and (17) measured the outcome based on Mean and S.D. The study (13) used mean and range for analysis. Chisquare test is used in study (16) and Linear regression equation in study (18).

Out of nine studies, four studies (11) (12)(13) and (17) based on association of Anguli pramana and Prakruti. One study (16) shows association of Anguli pramana with physical fitness while rest of the four studies (10) (14) (15) and (18) are exactly base on measurement of body parts as parameters as primary outcome. These all are the main outcomes of the concerned studies whereas we extracted that five studies (11) (12) (13) (16) and (17) showed the standard method of measurement as secondary outcome.

Out of nine studies five studies (11) (12) (14) (15) and (18) have reconfirmed that Breadth of middle finger $(\mathrm{BM})$ of right hand stands as more accurate method for measurement of Anguli pramana while in three studies (10) (13) and (17) average of right and left middle finger at proximal interphalangeal joint is used as a tool of measurement. Only one study (16) out of nine selected studies shows use of average of breadth of four fingers at metacarpophalangeal joints of right and left hand as a tool of measurement.

The shortcomings of this systematic review can be stated as very few studies on Anguli pramana are reported as PG dissertations mostly unpublished. Those which are published are also limited to association of Anguli pramana with life span, stature, prakruti (constitutional make-up) and physical fitness. Very few studies are focused on the core areas of standard method of measurement of Anguli pramana.

\section{Conclusion}

Individualistic approach is the specialty of ancient Anguli pramana; hence individual's own finger width is used as a tool of measurement of various human body parts. On the basis of present systematic review, it may be concluded that breadth of middle finger of the right hand at proximal interphalangeal joint is the standardized tool of measurement for Anguli pramana. Anthropometric measurements by Anguli pramana can be used for future epidemiological studies and serve as non-invasive public health marker for prediction of future risk of disease and to work out on preventive strategy. Anguli pramana is quite subjective or individualistic to implement, we hope that this Systematic review will bring objectivity to Anguli pramana. This systematic review will be served as source for other researchers for reference.

\section{References}

1. Thatte D. G. Sharir Rachana Vigyan. $2^{\text {nd }}$ edition. Varanasi; Chaukhambha Sanskrit Series Office; 2008. 637p

2. Srikantha Murthy K. R. Illustrated Sushrut Samhita of Acharya Sushruta. Volume-1. Reprint edition. Varanasi; Chaukhambha Orientalia; 2017. 245p

3. Singh Raghunath. Kautiliyam Arthashastram of Acharya Chanakya. Part 1. 1 1st edition. Varanasi; Krishnadas Academy; 1983. 420p

4. Pandit Shastri Parashuram editor. Sharangadhara Samhita of Acharya Sharangadhara with Adhamalla's Dipika and Kashiram's Gudhartha Dipika commentary. $1^{\text {st }}$ edition. Varanasi; Chaukhambha Surabharati Prakashana ; 2006. 9p

5. Vaidya Yadavaji Trikamji Acharya, editor. Sushruta Samhita of Acharya Sushruta with Nibandha Sangraha commentary of Shri Dalhanacharya on 
Nidanasthana, Reprint Edition. Varanasi, Chaukhambha Surbharati Prashana; 2012. pp 150

6. Trikamji aacharya and Narayanaramacharya Kavyathirtha. Sushrut Samhita of Sushruta with Nibhandha sangraha commentary of Sri Dalhanacharya and Nyayachandrika Panjika of Gayadas on Nidansthana. IX edition. Varanasi; Choukhambha Orientalia; 2007. 824p

7. Jain N. , Yadav S. K. Jain T. Anthropometric Study on Pramana of Uru and Jangha to Disperse Controversies Regarding Anguli Pramana, Ojas Panchakarma Peer Reviewed Journal of Holistic Health Management, Bhopal. October, 2016; 8(7); 12

8. Welch V, Petticrew M, Petkovic J, Moher D, Waters E, White H, Tugwell P. Extending the PRISMA statement to equity-focused systematic reviews (PRISMA-E 2012): explanation and elaboration; International Journal for Equity in Health, 2015; $14 ; 92$

9. Department of Preventive Medicine and Public Health, University of Navarre. Available online: http://www.unav.edu/departamento/preventiva/ publicaciones dated 3 May 2020 time 08:10 IST

10. Muley S, Surve A, Bhingare S. Scientific study of Charakokta Anguli Pramana in reference to Human height. AYU Oct-Dec, 2013; 34(4); 356-360

11. Pai R, Govidaraju U. Study on Pramana Shareera in relation to Prakriti. Journal of Ayurveda and Integrated Medical Sciences May-June, 2017; 2(3); 66-69
12. Sharma R, Kamble P, Bhati K. Study of Prakruti with perspective to Anguli Pramana, international Ayurvedic Medical Journal. May, 2015; 3(5); 1540-1543

13. Shilwant A, Bhutada S. Assessment of Vaksha and validation of Pruthupina vaksha in different Deha prakruti, World Journal of Pharmaceutical Research. September, 2018; 7(17); 893-899

14. Jain N, Bhatnagar V, Lahange S. Anthropometric study of Adhah Shakha w.s.r.to Anguli Pramana described in Brihattrayi. Journal of Ayurveda OctDec, 2017; 11(4); 70-76

15. Sharath S, Mishra B. Pramana of Jangha and its relation with the height of healthy individual, International Ayurvedic Medical Journal. Sep-Oct, 2013; 1(5); 1-7

16. Phule S, Patil G, Ghate U. Study of association of Charakokta Anguli Pramana with Physical fitness, International Journal of Research. June, 2019; 8(6), 5334-5343

17. Bhutada S, Shilwant A. Assessment of Bahu and validation of Pralamba Bahu in individuals with different Deha Prakriti. World Journal of Pharmaceutical Research. October, 2018; 7(18); 1016-1023

18. Singh A, Govida raju U. Pramāṇaśarīra with special reference to determination of Stature from Siras (Head) - A comprehensive study. Āryavaidyan. May-July, 2015; 28(4); 220-224. 